\title{
Research
}

\section{Socioeconomic factors influencing customary marine tenure in the Indo-Pacific}

\author{
$\underline{\text { Joshua Cinner }}^{1}$
}

\begin{abstract}
For generations communities in the Western Pacific have employed a range of resource management techniques (including periodic reef closures, gear restrictions, entry limitations, and the protection of spawning aggregations) to limit marine resource use. Localized control over marine resources, commonly known as customary marine tenure (CMT), is the legal and cultural foundation for many of these practices. Because of their perceived potential to meet both conservation and community goals, these traditional resource management techniques are being revitalized by communities, governments, and NGOs as an integral part of national and regional marine conservation plans in the Pacific. However, the viability of conservation strategies built on a foundation of marine tenure may be in question, as it remains unclear whether marine tenure systems will be able to withstand the profound social and economic changes sweeping the Pacific region. Numerous studies have suggested that changes in marine tenure are attributed to social and economic factors, however, specific relationships between socioeconomic conditions and marine tenure are still not well understood. This paper examines the social and economic characteristics of 21 coastal communities in Papua New Guinea and Indonesia, and explores the characteristics of the communities that employ exclusive marine tenure to answer the following questions: Which socioeconomic factors are related to the presence of CMT regimes? How might socioeconomic factors influence the ability of communities to employ or maintain CMT regimes? Distance to market, immigration, dependence on fishing, and conflicts were found to be related to the presence of highly exclusive marine tenure systems. Exploring these relationships will help conservation practitioners better understand how future social changes may influence the foundation of conservation and development projects.
\end{abstract}

Key Words: customary marine tenure; common-property; socioeconomic; Papua New Guinea; Indonesia.

\section{INTRODUCTION}

Contrary to Western society's propensity toward managing marine resources as open-access situations, another paradigm of common ocean governance called Customary Marine Tenure (CMT) is prevalent in parts of the Pacific. Under CMT, access to inshore marine resources is generally controlled by social units including individuals, families, clans or other kinship-based institutions, and villages (Carrier 1987, Ward 1997). These marine tenure institutions can range from relatively simple communally-owned marine areas from which outsiders are excluded to the complex and overlapping system of individual and family rights to space, species, gear, and even specific techniques of using gear described by Carrier (1987) and Cinner et al. (in press $a$ ) in the Manus province of Papua New Guinea (PNG). Although CMT has been documented throughout the World (Hviding 1996), it has reached the highest level of development in the Western Pacific (Ruddle and Akimichi 1984), including Japan (Ruddle 1985), Melanesia (Malinowski 1935, Hviding 1983, 1996, Wright 1985, Carrier 1987, Aswani 1999, 2002, Cooke et al. 2000, Foale and Macintyre 2000, Hickey and Johannes 2002), Polynesia (Hoffmann 2002), Micronesia (Johannes 1981, Zann 1985), Indonesia (Polunin 1984, Mantjoro 1996, Ruttan 1998, Harkes and Novaczek 2002), and Australia (Johannes and MacFarlane 1984). Legal recognition of marine tenure regimes can vary significantly 
between countries. For example, in PNG customary ownership of marine resources is formally recognized in the constitution (Hyndman 1993). Alternatively, much of neighboring Indonesia is open-access. However, in some northern and eastern regions of Indonesia (i.e., parts of Muluku, North Sulawesi, and West Papua provinces), de facto marine tenure systems still govern local access to marine resources (see Polunin 1984, Mantjoro 1996, Ruttan 1998, Harkes and Novaczek 2002).

In response to the degradation of inshore marine resources in many Pacific countries, governments and conservation groups are examining whether and how CMT regimes can be integrated into the modern conservation context (Cooke et al. 2000, Hoffmann 2002, Johannes 2002). CMT is particularly important in the context of resource management because it can serve as the legal and cultural foundation for other taboos such as gear prohibitions and spatial restrictions (Ruddle 1998, Aswani and Hamilton 2004). Where CMT is recognized, the highly decentralized authority over marine resources can also facilitate rapid adaptive response to changes in ecological or social conditions because decisions about limiting resource use can be made without the process of involving a centralized bureaucracy. Basing resource conservation initiatives around marine tenure regimes is particularly attractive to conservation organizations and donors because enforcement of specific fishing regulations within a tenure is generally the responsibility of the resource owner (Asafu-Adjaye 2000). By empowering community self-enforcement of fisheries regulations, CMT may provide a costeffective means to reduce the burden on government intervention, regulation, and enforcement (Johannes 1981, Hviding 1996, Ruddle 1998). This is particularly important in the economic context of the Pacific where fisheries departments are typically understaffed and under-funded (Johannes 1981).

Customary tenure regimes are the foundation of marine governance in much of the Pacific, but they must be better understood if they are to be effectively incorporated in resource management and development initiatives. In particular, very little is known about the social and economic frameworks that allow communities to employ or maintain CMT regimes. An array of theoretical and empirical research has shown that common property governance systems can be affected by socioeconomic factors such as religious or cultural homogeneity (Ostrom 1990), market influences (Hviding 1996, Henrich et al. 2001), transaction costs of decision-making (Ostrom 1990, Sumalde 2004), dependence on resources (Lise 2000, Agrawal 2001, Zanetell and Knuth 2004), social capital (Pretty and Ward 2001, Pretty 2003, Pretty and Smith 2004), conflicts (Polunin 1984, Adams et al. 2003) settlement patterns (Aswani 2002, Aswani and Hamilton 2004), and resource variability (see Agrawal 2002 for a comprehensive review of the factors influencing the emergence and successful functioning of common property institutions). The studies specific to CMT suggest that many of these social and economic factors can influence the nature and function of marine tenure institutions (Pollnac 1984, Polunin 1984, Baines 1989, Watson 1989, Hviding 1996, Cooke et al. 2000, Foale and Macintyre 2000, Aswani 2002), although specific relationships between socioeconomic conditions and CMT are sometimes contradictory and are still not well understood. For example, Watson (1989) discusses how changing socioeconomic conditions can render resource management strategies ineffective and inappropriate. Alternatively, Hviding (1996) documents how marine tenure rules became more exclusive for both commercial and subsistence activities in the Morovo Lagoon in response to increased prices of particular shells.

Here I ask the following questions: Which socioeconomic factors are related to the presence of CMT regimes? How might these socioeconomic factors influence the ability of communities to employ or maintain CMT regimes? To date, most research examining the social, economic, and cultural factors influencing CMT has utilized a relatively small number of cases or examined these issues over a very limited geographical area. Despite the important contributions that small $n$ case studies have made toward understanding CMT regimes, a fundamental limitation of this approach is that it does not allow us to discern larger patterns in how CMT regimes may respond to social and economic factors over a wider geographical context. In this paper, I seek to complement the more detailed case studies on the subject by using a comparative approach to examine the potential socioeconomic factors influencing viable CMT institutions in 21 coastal communities in Papua New Guinea and Indonesia. 


\section{METHODS}

\section{Data collection}

Between October 2001 and January 2003, research was conducted in 15 villages in Papua New Guinea (PNG) and six villages in North Sulawesi, Indonesia (Fig. 1). A number of criteria were used to select the study sites. Research was conducted as part of an interdisciplinary Wildlife Conservation Society project that assessed the effectiveness of coral reef conservation in the Indo-Pacific (Cinner et al. 2003; Cinner et al. in press $b$, McClanahan et al. unpublished data). Agrawal $(2001,2002)$ suggests that purposively selecting sites that have variation in theoretically significant variables is a defensible sampling methodology in a common-property research context. Study sites were purposively selected to encompass a wide range of social, economic, demographic, and resource governance conditions (e.g., varying degrees of remoteness, marine tenure, market influence, dependence on marine resources, etc.). However, as a result of the project's intent to integrate both socioeconomic and ecological data, site selection was constrained somewhat by the need to have comparable ecological parameters at each site (coral reef habitat, current regimes, exposure, etc.), access to SCUBA facilities (although live onboard dive boats were used to access two remote study sites in PNG and two in Indonesia), and project goals of examining several specific conservation sites of regional importance (e.g., Bunaken and Kilu). Based on the fact that the villages were not randomly selected, a cautious approach to interpreting the results would suggest that the conclusions drawn from this study are not necessarily applicable outside of the study sites.

Research was conducted over an one to three week period per village using one to four trained local assistants to aid in data collection. I used theoretical and empirical research (e.g., Ostrom 1990, Carrier and Carrier 1991, Agrawal 2001, Aswani 2002; Pollnac and Johnson in press) and socioeconomic assessment methodologies designed for coastal communities (Pollnac 1998, Bunce et al. 2000, Pollnac and Crawford 2000) to select indicators that were expected to be related to marine resource governance in the Indo-Pacific and that were also feasible to collect during the limited research time at each site. These were: population, distance to markets, the percentage of fish bartered or sold in the market, the type of settlement pattern, dependence on marine resources, immigration, the presence of conflicts over marine resources, and the exclusivity of marine tenure regimes.

A combination of systematic household surveys (for example, surveying every second or third household), semi-structured interviews with key informants (community leaders and resource users), recording of oral histories, transect walks (walking through the community with a local to identify and verify issues), participant observations, descriptions of daily and seasonal time-use, women's focus groups, and analyses of secondary sources such as population censuses and fisheries records were all used to gather information and triangulate results. A total of 954 household surveys were collected. Sampling within villages was based on a systematic sample design, where a sampling fraction of every $i^{\text {th }}$ house (e.g. $\left.2^{\text {nd }}, 3^{\text {rd }}, 4^{\text {th }}\right)$ was determined by dividing the total village population by the sample size (Henry 1990, de Vaus 1991). Variance from the systematic sample was assumed to be equal to the estimated variance based on a simple random sample (Scheaffer et al. 1996). The number of surveys per community ranged from 15-84 (Table 1 ), depending largely on the population of the village, the number of available research assistants, and the available time per site (this was influenced by factors such as weather, the availability and frequency of transportation to certain sites, and budget requirements such as the cost of the boat used to access remote sites).

The head of the household was interviewed. If the head of the household was not available, the household was revisited later. If the head of the household was still not available, another adult from the household was interviewed. The head of the household could have been either a male or female. In instances where it was appropriate, more than one member of the household was interviewed to obtain the most accurate information about specific subjects (for example, if a female headed the house but her eldest son was more knowledgeable about the household's fishing activities and practices, then he would be asked about the proportion of fish catch bartered or sold).

Household surveys were used to gather the following indicators: dependence on fishing, immigration, population of the village, and the percentage of fish sold in the market. Dependence 
Fig. 1. Map of study sites.

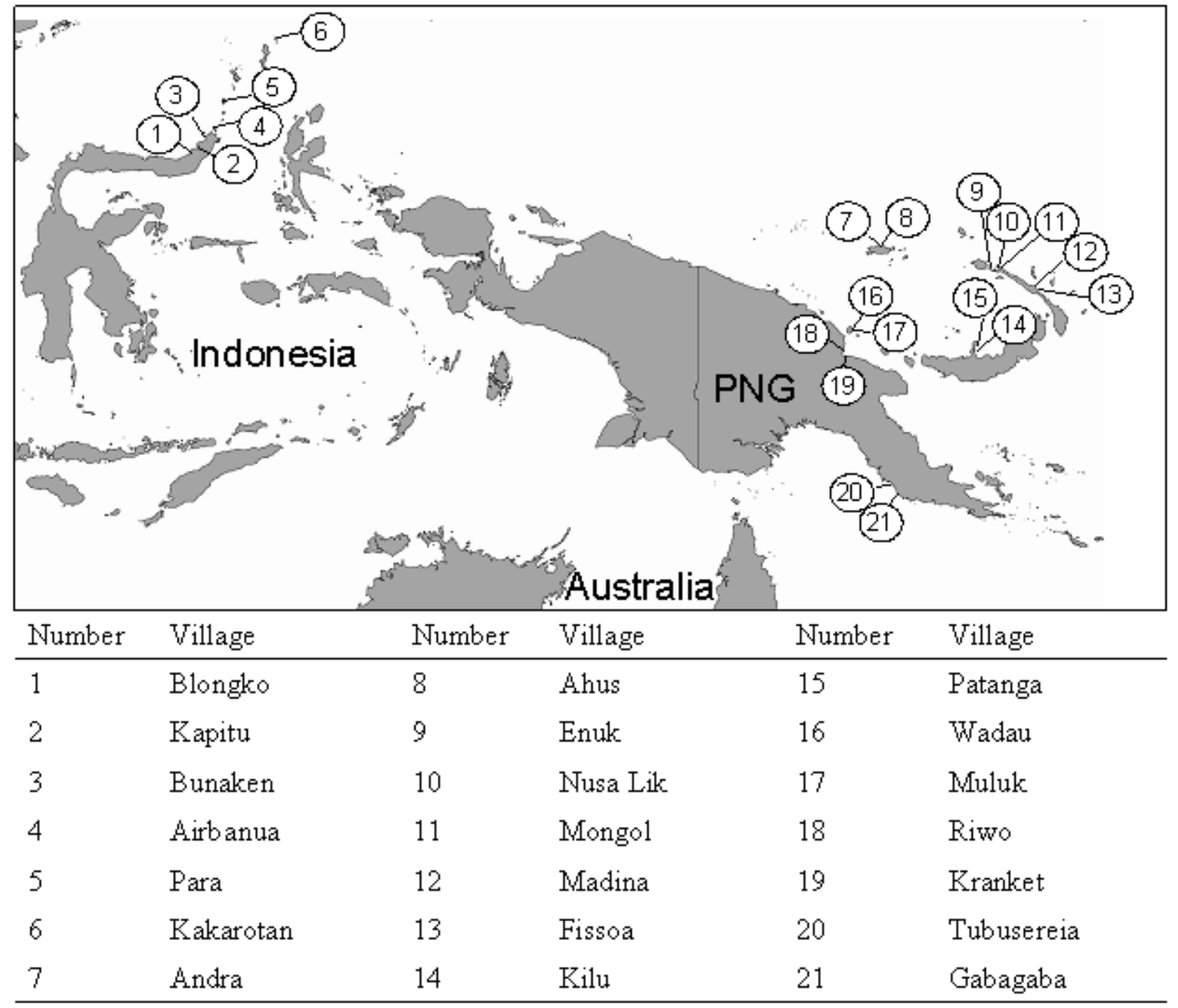

on fishing was determined by having respondents list all the occupations the household engaged in for food or money. Respondents were then asked to rank these activities in order of importance. Those who regularly engaged in fishing estimated the percentage of their fish catch sold or bartered. Respondents were asked where they were from and were considered immigrants if they came from another village. Population was determined by: (1) counting the number of houses, (2) determining the average number of persons per household (adults and children) from the household surveys, and (3) multiplying this by the number of houses in the community. This was thought to be more accurate than relying on census information because the census record in one community reported almost twice as many houses as were actually counted.

Key informants were selected using non-probability sampling techniques, including convenience sampling (for example, a respondent may be approached during resource use activities) or snowball sampling (where community members will suggest appropriate respondents) (Henry 1990). Between two and fifteen key informants were interviewed per village. Key informants also provided information on how exclusive the marine tenure was. Based on the key informant interviews 
Table 1. Summary of study sites.

\begin{tabular}{|c|c|c|c|c|c|c|c|c|c|}
\hline Village & $\begin{array}{l}\text { Exclude } \\
\text { non-own- } \\
\text { ers }\end{array}$ & $\begin{array}{l}\text { Settlement } \\
\text { pattern }\end{array}$ & $\begin{array}{l}\text { Conflicts over } \\
\text { marine res- } \\
\text { ources }\end{array}$ & Population & $\begin{array}{l}\text { Distance } \\
\text { to market } \\
(\mathrm{km})\end{array}$ & $\begin{array}{c}\% \\
\text { immigrants }\end{array}$ & $\begin{array}{l}\% \text { of fish } \\
\text { bartered } \\
\text { or sold }\end{array}$ & $\begin{array}{l}\% \text { ranked } \\
\text { fishing as } \\
\text { primary occ- } \\
\text { upation }\end{array}$ & $\begin{array}{c}\# \text { of } \\
\text { household } \\
\text { surveys }\end{array}$ \\
\hline Ahus & yes & nucleated & yes & 544 & 21 & 3.9 & 68 & 77 & 51 \\
\hline Andra & yes & nucleated & yes & 479 & 31 & 13.6 & 75 & 55 & 44 \\
\hline Gabagaba & yes & nucleated & yes & 1708 & 58 & 2.6 & 66 & 51 & 38 \\
\hline Kakarotan & yes & nucleated & yes & 730 & 100 & 2.0 & 24 & 27 & 48 \\
\hline Madina & yes & dispersed & no & 564 & 70 & 35.0 & 13 & 0 & 32 \\
\hline Muluk & yes & nucleated & yes & 333 & 69 & 7.5 & 44 & 5 & 41 \\
\hline Para & yes & dispersed & yes & 1513 & 46 & 27.0 & 69 & 56 & 59 \\
\hline Airbanua & no & dispersed & no & 687 & 45 & 32.6 & 52 & 12 & 43 \\
\hline Blongko & no & nucleated & no & 1332 & 32 & 51.9 & 44 & 8 & 77 \\
\hline Bunaken & no & dispersed & yes & 3122 & 16 & 20.5 & 72 & 37 & 73 \\
\hline Enuk & no & nucleated & no & 272 & 14 & 27.3 & 64 & 24 & 33 \\
\hline Fissoa & no & dispersed & no & 287 & 85 & 14.0 & 18 & 0 & 31 \\
\hline Kapitu & no & dispersed & no & 1791 & 60 & 57.1 & 66 & 18 & 84 \\
\hline Kilu & no & dispersed & no & 584 & 17 & 25.0 & 31 & 0 & 40 \\
\hline Kranget & no & nucleated & no & 2127 & 1 & 29.7 & 67 & 35 & 37 \\
\hline Mongol & no & nucleated & no & 493 & 0 & 64.3 & 35 & 18 & 28 \\
\hline Nusa Lik & no & nucleated & no & 273 & 1 & 46.2 & 69 & 54 & 15 \\
\hline Patanga & no & dispersed & no & 421 & 20 & 26.8 & 26 & 0 & 41 \\
\hline Riwo & no & dispersed & no & 1136 & 7 & 10.8 & 56 & 24 & 37 \\
\hline Tubuseria & no & nucleated & no & 5000 & 25 & 12.8 & NA & 18 & 61 \\
\hline Wadau & no & nucleated & no & 324 & 66 & 10.0 & 38 & 2 & 41 \\
\hline
\end{tabular}

and confirmed observations, villages were classified based on whether they: (1) practiced highly exclusive marine tenure regimes in which non-owners had to ask permission to access marine resources (classified as "strong" or "highly exclusive" marine tenure), or (2) had less exclusive or no marine tenure regimes in which non-owners regularly and openly accessed marine resources without asking permission (classified as "weak" or "less exclusive" marine tenure). Situations in which neighboring villages (non-owners) had been granted revocable use privileges and regularly accessed marine resources were also classified as less exclusive. Although this compartmentalization 
of a wide range of marine tenure regimes into comparable categories have undoubtedly lead to overly simplistic interpretations of their true complexities (Hviding 1996, McCay and Jentoft 1998), it is hoped that this will be outweighed by the ability to examine how marine tenure is related to different social and economic factors that can be captured best through a broader-scale comparative study.

Key informants and secondary sources provided information on the presence of serious or significant conflicts over marine resources. I defined conflicts as intense verbal confrontations, use of violence, or court cases. Communities that reported conflicts over the previous 12 months or had court cases pending were considered to have conflicts. Key informants also provided information on the nearest market where marine products were regularly bought and sold. The distance from the village to markets were measured on topographic maps and nautical charts. Communities were grouped into two types of settlement patterns: dispersed or nucleated. Dispersed settlements were communities that were spread out and contained distinct sub-villages that were geographically separated. For example, the community of Riwo in Madang, PNG, had subvillages on two separate islands and was thus considered a dispersed settlement. Nucleated settlements were communities that were relatively contiguous.

\section{Analyses}

The socioeconomic characteristics of communities that excluded all non-owners from accessing resources within their tenure were compared to the characteristics of communities where non-owners were allowed to access marine resources. Four types of analyses were performed to discern whether the presence of highly exclusive marine tenure was related to socioeconomic factors: the Mann Whitney U test, Fisher's Exact test, effect size, and statistical power.

The SPSS 11.01 statistical program was used to determine statistical significance with the MannWhitney U and Fisher's Exact tests. The MannWhitney $U$ test is a non-parametric alternative to the T-test, which is used to test whether two samples are independent (Siegel and Castellan 1988). The Mann-Whitney U test was used to examine whether ordinal or interval socioeconomic characteristics of communities with highly exclusive tenure were significantly different from communities with low excludability. For example, I used the Mann Whitney $U$ test to compare the mean (rank of) percentage of immigrants in communities with highly exclusive marine tenure to the mean (rank of) percentage of immigrants in communities with weaker marine tenure. The frequency of dichotomous data (i.e., settlement patterns and the presence of conflicts) in communities with strong marine tenure was compared to communities with weak marine tenure using a Fisher's Exact test. The Fisher's Exact test is a non-parametric analysis used to discern whether two samples are independent based on the frequency of observed responses in a $2 \times 2$ contingency table with small independent samples (Siegel and Castellan 1988). Liberal $p$ values were accepted for determining statistical significance $(p<0.1)$, because this is an exploratory analysis and, based on the moderate sample size of 21 villages, I did not want to exclude any variables that might be important (i.e., I thought the consequences of committing a type I error were more grave than a type II error). To ensure nationallevel differences were not driving any of the patterns, significant differences between socioeconomic characteristics for Indonesian and New Guinean sites were tested for as well.

Effect size is a standardized measure of the strength of the relationship between independent and dependent variables (Vaske et al. 2002). The Hedge's effect size was calculated as the difference between the mean socioeconomic conditions of the two groups (e.g., mean distance to market of the communities that employed exclusive marine tenure regimes minus the mean distance to market of the communities that did not) divided by the pooled standard deviation of both groups (Gliner et al. 2001). Statistical power is the probability of finding a statistically significant result when there is a real effect in the population being studied (i.e., rejecting the null hypothesis when a research hypothesis is true) (Cohen 1988). The power of these relationships was calculated using Statistica 6.0 statistical program. 


\section{RESULTS}

\section{Socioeconomic characteristics of communities}

The 21 communities varied considerably in the socioeconomic and governance indicators (Table 1). Communities ranged from small hamlets with only 272 people to large villages of 5,000 people. The importance of fishing as a livelihood strategy varied considerably in the communities examined. The percentage of households that ranked fishing as the primary occupation varied from $0-77 \%$, with a mean of $25 \%$. There was also a considerable range in the market influence (measured as distance to market and the percentage of fish bartered or sold) on the communities. Communities ranged from $0-100 \mathrm{~km}$ from markets. The mean distance to the nearest regular market for marine products for all sites was $37 \mathrm{~km}$ and the median distance was $32 \mathrm{~km}$. The percentage of fish bartered or sold ranged from $13-72 \%$ and had a mean of $50 \%$. The percentage of immigrants ranged from $2-64 \%$, with a mean and median of $25 \%$. Twelve of the 21 sites were nucleated settlements and only seven sites reported conflicts over marine resources. Seven of the 21 communities regularly excluded non-owners from accessing marine resources. High excludability occurred in the Sangihe-Talaud part of North Sulawesi, Indonesia ( Para and Kakarotan communities), but not the southern communities on or near the main island. In New Guinea, high excludability was reported throughout the country.

\section{Socioeconomic factors influencing marine tenure}

Only the population indicator differed significantly between the sites in New Guinea and Indonesia. The mean population for the New Guinean sites (970) was significantly lower than the mean population for the Indonesian sites (1530) $(\mathrm{U}=17, p<0.05)$. This lack of difference between countries for other indicators suggests that national-level differences in marine tenure or socioeconomic conditions did not overly influence the analysis.

Four out of seven variables differed significantly between villages with highly exclusive marine tenure and those with less exclusive tenure regimes (Table 2). The presence of conflicts over marine resources was correlated to the presence of highly exclusive marine tenure. The percentage of immigrants was lower in communities with exclusive marine tenure, the distance to market was higher in communities with exclusive marine tenure, and the percentage of households dependent on fishing was higher in communities with exclusive marine tenure (although this relationship was only significant at the $\mathrm{p}<0.1$ level). The large effect size of these latter three relationships $(d>0.93)$ suggests that substantial relationships exists (Vaske et al. 2002) (Table 2). No statistically significant differences were found in settlement pattern, population, or the percentage of fish sold in market between communities with strong and weak marine tenure. The effect size of the percentage of fish sold in markets $(d=0.1)$ was very low, suggesting a minimal relationship (Vaske et al. 2002). However, the power of this relationship was also very low $(0.05)$, so it would be difficult to detect differences. The effect size of population $(d=0.37)$ was approaching a typical relationship found in the social sciences $(d=0.5)$ (Vaske et al. 2002), and the power of this relationship was low $(0.12)$ so the effect of population may have been real but not detectable with the sample size used. Note that effect sizes and power are not computed for dichotomous indicators (such as settlement pattern and conflicts).

\section{DISCUSSION}

This is one of the first studies to quantitatively explore relationships between socioeconomic factors and marine tenure over a large spatial scale with a moderate sample size. This paper found that communities with strong marine tenure were further from markets, had lower migration, but had higher dependence on fishing and conflicts over marine resources. This study is an important compliment to the more localized case studies and helps put such research into a broader context. For example, Aswani's comparison of marine tenure in the Roviana and Vonavona lagoons in the Solomon Islands provide a model for how socioeconomic and historical factors can result in three marine tenure patterns (Aswani 1999, 2002, Aswani and Hamilton 2004). Aswani's interpretations of how historical processes, socioeconomic factors, and demographic changes affect marine tenure in two coastal villages in the Solomon Islands suggest market forces and other exogenous pressures will not necessarily transform CMT institutions into open-access regimes (Aswani 1999, 2002). This study found that the distance to the market was negatively related to 
Table 2. Differences in socioeconomic characteristics of communities with and without exclusive marine tenure.

\begin{tabular}{|c|c|c|c|c|}
\hline Variable & Z score & $P$ & $\begin{array}{l}\text { Standardized } \\
\text { effect size (d) }\end{array}$ & Power \\
\hline Distance to market ${ }^{\mathrm{A}}$ & -2.24 & $0.03 * *$ & 0.97 & 0.51 \\
\hline Immigration $^{\mathrm{A}}$ & -2.16 & $0.03 * *$ & 0.97 & 0.51 \\
\hline Fishing as primary occupation ${ }^{\mathrm{A}}$ & -1.69 & $0.09 *$ & 0.93 & 0.50 \\
\hline Conflicts $^{\mathrm{B}}$ & NA & $0.001 * * *$ & NA & NA \\
\hline $\begin{array}{l}\text { Percentage of fish } \\
\text { sold in market }\end{array}$ & -0.59 & 0.44 & 0.1 & 0.05 \\
\hline Population $^{\mathrm{A}}$ & 0 & 1 & 0.37 & 0.12 \\
\hline Settlement pattern ${ }^{\mathrm{B}}$ & NA & 0.32 & NA & NA \\
\hline \multicolumn{5}{|c|}{$\begin{array}{l}\text { AC Computed using Mann Whitney U test. } \\
{ }^{\mathrm{B}} \text { Computed using Fisher's exact test. } \\
{ }^{* *} \text { Indicates a statistically significant relationship at alpha? }=0.001 \\
* * \text { Indicates a statistically significant relationship at alpha?=0.05 } \\
* \text { Indicates a statistically significant relationship at alpha }=0.1 \\
\text { NA= not applicable because the variables were dichotomous. }\end{array}$} \\
\hline
\end{tabular}

the exclusivity of marine tenure regimes, but whether the fishery was market or subsistencebased (measured in the percentage of fish bartered or sold) was not significant. This suggests that the strength of marine tenure institutions may be undermined by connectivity to larger markets, perhaps by introducing new ways of providing credit and generating prestige (Agrawal 2002). Commercial or market value for marine products, however, may not necessarily diminish the strength of tenure institutions.

To date, conclusions about how heterogeneity influences the development and maintenance of common property institutions remain inconclusive. Heterogeneity (which can include the often interrelated economic, cultural, religious, and resource use differences in a society) has been shown to have positive, negative, or minimal effects on common property management (Ruttan and Borgerhoff Mulder 1999, Glaesel 2000, Pollnac et al. 2001, Bardhan and Dayton-Johnson 2002; Pollnac and Johnson in press). This study found a lower proportion of immigrants in communities with highly exclusive marine tenure institutions, which is consistent with notions of high social capital being an important component of maintaining common-property management regimes (Pretty 2003). Cultural heterogeneity associated with immigration may act to increase the transaction costs of developing, maintaining, and enforcing marine tenure regulations (Aswani and Hamilton 2004). Trust, reciprocal arrangements, and consistent norms are important components of social capital (Pretty and Smith 2004) that may be affected by a high proportion of immigrants. Likewise, immigrants may not perceive the rules, processes, and authorities governing marine tenure to be legitimate, and thus may not comply with established rules (Sutinen and Kuperan 1999).

The relationship found between high dependence on marine resources and the exclusivity of marine tenure regimes is consistent with research on an array of common pool resources that suggests a positive relationship may exist between resource dependence and participation in common property arrangements (Lise 2000, Agrawal 2002, Zanetell 
and Knuth 2004). Communities with high dependence on marine resources may employ exclusive marine tenure regimes to increase livelihood security. For example, the Andra and Ahus Island study sites in Manus, PNG, are small infertile islands surrounded by large $\left(>5 \mathrm{~km}^{2}\right)$ reef lagoons. Islanders have limited access to essential terrestrial resources (e.g., vegetables and firewood) and consequently their dependence on marine resources is very high (Cinner et al. in press $a$ ). These communities claim exclusive rights to marine resources on the reefs surrounding their islands and reefs along the coast of the main Manus Island (Carrier 1987, Carrier and Carrier 1989; Cinner et al. in press $a$ ), preventing mainland communities from accessing marine resources. These exclusive marine tenure regimes help to create an economic monopoly on marine resources among fishing communities (Malinowski 1935) and help to ensure that island communities have desirable goods to sell or trade in local markets (Carrier 1987; Cinner et al. in press a), thereby improving their livelihood security.

There are several possible explanations for the relationship between the presence of conflicts and exclusive marine tenure regimes. Some researchers suggest that marine tenure regimes may have developed in response to conflicts and may serve to mitigate them (Pollnac 1984, Polunin 1984). On the other hand, the complexity of use rights associated with marine tenure institutions can cause them to be continually challenged (Foale and Macintyre 2000). In Indonesia, the lack of legal recognition of marine tenure also seemed to cause conflicts over marine resources. For example, while researching in Para Island, North Sulawesi, long-standing tenure rights were challenged by neighboring communities who claimed that exclusive tenure rights were not legal under Indonesia's constitution and attempted to fish in Para's fishing grounds. The Para community responded by brandishing a firearm to chase off fishers from the other community. Interrelationships among indicators may also help to explain the relationship between conflicts and exclusive marine tenure regimes. For example, communities with exclusive marine tenure regimes (with high dependence on marine resources) used confiscation of fishing equipment, intimidation, and even violence to enforce their tenure. Communities with lower dependence on marine resources may find the additional livelihood security that might be gained from employing exclusive marine tenure is not worth engaging the conflicts associated with this type of territory defense.

Several of the factors expected to be related to the presence of CMT did not demonstrate significant relationships, including population and settlement patterns. In a review of the factors influencing the sustainability of common property institutions, Agrawal (2002) notes that debates concerning the effect of population on common property institutions are highly polarized. Results from this study as to the effect of population on the presence of exclusive marine tenure regimes are inconclusive. The possibility exists that the sample size used here was too small to detect differences in these indicators, particularly considering the effect size for population was approaching a moderate effect. More interestingly though, is the possibility that the populations in the communities studied were too small to detect any effect. Gabagaba and Para were two of the five largest communities in my study (the $4^{\text {th }}$ and $5^{\text {th }}$ largest populations, respectively), but employed CMT (Table 1). These communities had populations of fewer than 2,000 and the largest population of any community studied was 5,000 residents. Harkes and Novaczek (2002) found that traditional management in Indonesia (called Sasi) dies out in villages greater than 3,000 people. However, Evans et al. (1997) noted that Sasi was present in a community larger than 14,000 people. Therefore, based on previous research, the critical population size at which CMT may cease to function effectively may not have been reached in this study (or reached by only the two sites with populations $>3,000$ ). The population levels of many of the study sites were similar to many rural coastal areas in the provinces studied (e.g., National Statistics Office 2002a, b), however, urbanized areas with high populations were not examined. An interesting area of further inquiry would be to examine whether or how communities with tens of thousands of residents could support highly exclusive marine tenure regimes. Aswani (2002), and Aswani and Hamilton (2004) also speculated that nucleated and dispersed settlement patterns influenced whether and how communities in the Solomon Islands could develop and maintain marine tenure regimes. Although this study was not able to explore in-depth ethnographic accounts of settlement histories, no relationship was found between settlement patterns and the strength of marine tenure institutions. In the broader context, this suggests that whether communities are nucleated or dispersed may be less important than other socioeconomic factors in maintaining marine 
tenure regimes.

One of the initial concerns with this study was that national or regional factors might overshadow the village level factors examined. However, this did not appear to be the case: there were few significant differences in socioeconomic characteristics between the two countries and several adjacent or nearby communities reported different marine tenure regimes, supporting the notion that marine tenure can vary in response to village-level factors and is not only a product of regional sociocultural influences. For example, Madina and Fissoa were nearby communities of a common language group, but Madina had high excludability and Fissoa had low excludability. Another potential concern was that intersite variability in the resource might have been very high, which could conceivably influence the nature of the marine tenure institutions. Incorporating the ecological criteria in site selection provided a reasonable assurance that relatively little variance existed in the resources within each tenure (i.e., the tenure areas all contain comparable coral reefs in similar ecological zones). Furthermore, we can infer from other analyses of the resources within these sites (Cinner et al. unpublished data; Cinner et al. in press-b; Cinner and McClanahan unpublished data) that many of the commercially valuable species harvested within the tenure sites such as trochus, beche de mer, and reef fish have small home ranges (e.g., on the scale of hectares to kilometers) (Kramer and Chapman 1999) congruent to the scale of the tenure areas. Therefore, the possible variance in resource conditions is expected to have relatively little influence in the observed tenure institutions.

\section{Speculation}

This study was able to tease out several indicators that were of more importance than others and provide qualitative descriptions of how these factors may be related to the presence of CMT. The limitations inherent in the non-random design of this study mean these results apply only to these study sites and should not be generalized to the wider region. Keeping in mind the limitations of this study's methodology, it is important to speculate on whether and how these regimes will be able to adapt and respond to changes in socioeconomic conditions.

Marine tenure systems are dynamic institutions that, through adaptation to changing scenarios, have proven relatively robust to population pressures and aspects of economic and political modernization (Hviding 1998). However, Asia-Pacific is a region undergoing profound social, economic, and demographic changes (UNEP 2002), and there may be social forces that marine tenure regimes are unable to adapt to. Results from this study suggest that socioeconomic changes that will increase immigration, open new markets, and decrease dependence on marine resources may influence the ability of communities to employ or maintain exclusive marine tenure regimes. Under these scenarios, conservation and development strategies that rely on high excludability in a community's tenure may become challenged at their foundation.

Alternatively, results from this study also suggest CMT may be somewhat resilient to other socioeconomic factors such as population growth. Highly exclusive CMT can operate in communities with populations of 1,700 , but strong CMT is related to low levels of immigration. This suggests that high endogenous population growth (i.e., not from immigration) in smaller communities may not affect the ability to employ viable marine tenure.

The next research challenge is to address the applicability of these results to the wider region. A random selection of villages that could be considered representative of the region would be desirable for future studies. Another research priority is determining what specific aspects of these variables influence marine tenure. For example, high immigration may cause confusion over use rights, disrupt traditional information exchange mechanisms, and/or introduce new ideas that challenge traditional practices. A better understanding of how these factors influence marine tenure regimes will allow development and conservation organizations to target capacity building and other activities to potentially increase the resilience of Pacific conservation strategies against the forces of social change.

Responses to this article can be read online at: http://www.ecologyandsociety.org/vollo/iss 1/art36/responses/

\section{Acknowledgments:}

I thank the people and leaders of all 21 villages for 
allowing me to work in their communities. Thanks to LIPI, the PNG National Research Council, PNG Department of Environment and Conservation, and the PNG National Fisheries Authority. The David and Lucille Packard Foundation supported this research through the Wildlife Conservation Society. Thanks to S. Sutton, R. Arthur, J. Carrier, and three anonymous reviewers for reviewing this manuscript and providing extremely helpful and constructive comments.

\section{LITERATURE CITED}

Adams, W., D. Brockington, J. Dyson, and B. Vira. 2003. Managing tragedies: understanding conflict over common pool resources. Science 302:1915-1916.

Agrawal, A. 2002. Common resources and institutional stability in E. Ostrom, T. Dietz, N. Dolsak, P. Stern, S. Stonich, and E. Weber, editors. The drama of the commons. National Academies Press, Washington, D.C., USA.

Agrawal, A. 2001. Common property institutions and sustainable governance of resources. World Development 29:1649-1672.

Asafu-Adjaye, J. 2000. Customary marine tenure systems and sustainable fisheries management in Papua New Guinea. International Journal of Socio Economics 27:917-926.

Aswani, S., and R. Hamilton. 2004. Integrating indigenous ecological knowledge and customary sea tenure with marine science and social science for conservation of bumphead parrotfish (Bolbometopon muricatum) in the Roviana Lagoon, Solomon Islands. Environmental Conservation 31:69-83.

Aswani, S. 2002. Assessing the effects of changing demographic and consumption patterns on sea tenure regimes in the Roviana Lagoon, Solomon Islands. AMBIO 31:272-284.

Aswani, S. 1999. Common property models of sea tenure: a case study from the Roviana and Vonavona Lagoons, New Georgia, Solomon Islands. Human Ecology 27:417-453.
Baines, G. 1989. Traditional resource management in the Melanesian South Pacific: a development dilemma. Pages 54-69 in F. Berkes, editor. Common property resources: ecology and community-based sustainable development. Belhaven Press, London, England.

Bardhan, P., and J. Dayton-Johnson. 2002. Unequal irrigators in E. Ostrom, T. Dietz, N. Dolsak, P. Stern, S. Stonich, and E. Weber, editors. The drama of the commons. National Academies Press, Washington, D.C., USA.

Bunce, L., P. Townsley, R. S. Pomeroy, and R. B. Pollnac. 2000. Socioeconomic manual for coral reef management. Australian Institute of Marine Science, Townsville, Australia.

Carrier, J. 1987. Marine tenure and conservation in Papua New Guinea. Pages 143-167 in B. McCay, and J. Acheson, editors. The Question of the commons: the culture and ecology of common resources. The University of Arizona Press, Tucson, Arizona, USA.

Carrier, J., and A. Carrier. 1991. Structure and process in a Melanesian society: Ponam's progress in the twentieth century. Harwood Academic Publishers, Paris, France.

Carrier, J., and A. Carrier. 1989. Wage, trade, and exchange in Melanesia: a Manus society in the modern state. University of California Press, Berkeley, California, USA.

Cinner, J., J. Ben, and M. Marnane. 2003. How socioeconomic monitoring can assist marine reserve management: Kimbe Bay, Papua New Guinea in C. Wilkinson, and A. Green, editors. Monitoring coral reef marine protected areas. Australian Institute for Marine Science, Townsville, Australia.

Cinner, J., T. H. Clark, M. Marnane, T. McClanahan, and J. Ben. In press a. Trade, tenure, and tradition: influence of sociocultural factors on resource use in Melanesia. Conservation Biology.

Cinner, J., M. Marnane, T. McClanahan, and T. H. Clark. In press b. Conservation and community benefits from traditional coral reef management at Ahus Island, Papua New Guinea. Conservation Biology. 
Cohen. 1988. Statistical Power Analysis for Behavioral Sciences. Lawrence Erlbaum Associates, Hillsdale, New Jersey, USA.

Cooke, A. J., N. V. C. Polunin, and K. Moce. 2000. Comparative assessment of stakeholder management in traditional Fijian fishing-grounds. Environmental Conservation 27:291-299.

de Vaus, D. A. 1991. Surveys in social research. UCL, London, England.

Evans, S. M., M. E. Gill, A. S. W. Retraubun, J. Abrahamz, and J. Dangeubun. 1997. Traditional management practices and the conservation of the gastropod (Trochus nilitocus) and fish stocks in the Maluku Province (Eastern Indonesia). Fisheries Research 31:83-91.

Foale, S., and M. Macintyre. 2000. Dynamic and flexible aspects of land and marine tenure at West Nggela: implications for marine resource management. Oceania 71:30-45.

Glaesel, H. 2000. State and local resistance to the expansion of two environmentally harmful marine fishing techniques in Kenya. Society and Natural Resources 13:321-338.

Gliner, J., G. Vaske, and G. Morgan. 2001. Null Hypothesis significance testing: effect size does matter. Human Dimensions of Wildlife 6:291-301.

Harkes, I., and I. Novaczek. 2002. Presence, performance, and institutional resilience of sasi, a traditional management institution in Central Maluku, Indonesia. Ocean and Coastal Management 45:237-260.

Henrich, J., R. Boyd, S. Bowles, H. Gintis, C. Camerer, F. Ernst, and R. McElreath. 2001. In search of homo economicus: behavioral experiments in fifteen small-scale societies. American Economic Review 91:73-78.

Henry, G. T. 1990. Practical sampling. Sage Publications, Newbury Park, California, USA.

Hickey, F., and Johannes, R. E. 2002. Recent evolution of village-based marine resource management in Vanuatu. SPC Traditional Management Bulletin 14:8-21.
Hoffmann, T. C. 2002. The reimplementation of the Ra'ui: coral reef management in Rarotonga, Cook Islands. Coastal Management 30:401-418.

Hviding, E. 1998. Contextual flexibility: present status and future of customary marine tenure in Solomon Islands. Ocean and Coastal Management 40:253-269.

Hviding, E. 1996. Guardians of the Marovo Lagoon: Practice, place, and politics in maritime Melanesia. University Press of Hawai'i, Honolulu, Hawaii, USA.

Hviding, E. 1983. Keeping the sea: aspects of marine tenure in Marovo lagoon, Solomon Islands. Pages 9-44 in K. Ruddle, and R. E. Johannes, editors. Traditional marine resource management in the Pacific Basin: an anthology. UNESCO, Jakarta, Indonesia.

Hyndman, D. 1993. Sea tenure and the management of living marine resources in Papua New Guinea. Pacific Studies 16:99-114.

Johannes, R. E. 2002. The renaissance of community-based marine resource management in Oceania. Annual Review of Ecological Systems 33:317-340.

Johannes, R. E. 1981. Words of the lagoon: fishing and marine lore in the Palau district of Micronesia. University of California Press, Berkeley, California, USA.

Johannes, R. E., and J. W. MacFarlane. 1984. Territorial sea rights in the Torres Strait Islands with emphasis on Murry Island in K. Ruddle, and T. Akimichi, editors. Maritime institutions in the Western Pacific. National Museum of Ethnology, Osaka, Japan.

Kramer, D. L., and M. R. Chapman. 1999. Implications of fish home range size and relocation for marine reserve function. Environmental Biology of Fishes 55:65-79.

Lise, W. 2000. Factors influencing people's participation in forest management in India. Ecological Economics 34:379-392.

Malinowski, B. 1935. Coral gardens and their magic. George Allen and Unwin, London, England. 
Mantjoro, E. 1996. Management of traditional common fishing grounds: the experience of the Para community, Indonesia. Coastal Management 24:229-250.

McCay, B., and S. Jentoft. 1998. Market or community failure: critical perspectives on common property research. Human Organization 57:21-29.

National Statistics Office. 2002a. Census unit register: Madang province. National Statistics Office, Port Moresby.

National Statistics Office. 2002b. Census unit register: Manus province. National Statistics Office, Port Moresby.

Ostrom, E. 1990. Governing the commons: the evolution of institutions for collective action. Cambridge University Press, Cambridge, United Kingdom.

Pollnac, R. B. 1998. Rapid assessment of management parameters for coral reefs. University of Rhode Island, Coastal Resources Center, Narragansett, Rhode Island, USA.

Pollnac, R. B. 1984. Investigating territorial use rights among fishermen. Pages 267-284 in K. Ruddle, and T. Akimichi, editors. Maritime Institutions in the Western Pacific. National Museum of Ethnology, Osaka, Japan.

Pollnac, R. B., and B. Crawford. 2000. Assessing behavioral aspects of coastal resource use. Coastal Resources Center, University of Rhode Island, Narragansett, Rhode Island, USA.

Pollnac, R. B., B. R. Crawford, and M. Gorospe. 2001. Discovering factors that influence the success of community-based marine protected areas in the Visayas, Philippines. Ocean and Coastal Management 44:683-710.

Pollnac, R. B., and J. C. Johnson. In press. Folk management and conservation of marine resources: towards a theoretical and methodological assessment in N. Kishigami, and J. Savelle, editors. Indigenous use and management of marine resources. National Museum of Ethnology, Osaka, Japan.

Polunin, N. V. C. 1984. Do traditional marine "reserves" conserve? A view of Indonesian and New
Guinean evidence. Pages 267-284 in K. Ruddle, and T. Akimichi, editors. Maritime institutions in the Western Pacific. National Museum of Ethnology, Osaka, Japan.

Pretty, J. 2003. Social capital and the collective management of resources. Science 302:1912-1914.

Pretty, J., and D. Smith. 2004. Social capital in biodiversity conservation and management. Conservation Biology 18:631-638.

Pretty, J., and H. Ward. 2001. Social capital and the environment. World Development 29:209-227.

Ruddle, K. 1998. The context of policy design for existing community-based fisheries management in the Pacific Islands. Ocean and Coastal Management 40:105-126.

Ruddle, K. 1985. The continuity of traditional management practices: the case of Japanese coastal fishing. Pages 159-179 in K. Ruddle, and R. E. Johannes, editors. The traditional knowledge and management of coastal systems in Asia and the Pacific. United Nations Environmental and Cultural Organization, Jakarta Pusat, Indonesia.

Ruddle, K., and T. Akimichi. 1984. Introduction in K. Ruddle, and T. Akimichi, editors. Maritime institutions in the Western Pacific. National Museum of Ethnology, Osaka, Japan.

Ruttan, L. M. 1998. Closing the commons: cooperation for gain or restraint? Human Ecology 26:43-66.

Ruttan, L. M., and M. Borgerhoff Mulder. 1999. Are East African pastoralists truly conservationists? Current Anthropology 40:621-652.

Scheaffer, R. L., W. I. Mendenhall, and L. Ott. 1996. Elementary survey sampling. Wadsworth, Belmont, California, USA.

Siegel, S., and N. J. Castellan. 1988. Nonparametric statistics for the behavioral sciences. McGraw-Hill, New York, USA.

Sumalde, Z. 2004. Transaction costs of community-based coastal resource management: the case of San Miguel Bay, Philippines. Coastal Management 32:51-60. 
Sutinen, J. G., and K. Kuperan. 1999. A socioeconomic theory of regulatory compliance. International Journal of Socio Economics 26:174-193.

UNEP. 2002. Global environmental outlook 3: past, present, and future perspectives. Earthscan Publications Ltd., London, England.

Vaske, G., J. Gliner, and G. Morgan. 2002. Communicating judgements about practical significance: effect size, confidence intervals, and odds ratios. Human Dimensions of Wildlife 7:287-300.

Ward, G. R. 1997. Changing forms of communal tenure. Page 13 in $\mathrm{P}$. Larmour, editor. The governance of common property in the Pacific Region. National Centre for Development Studies, Australian Nation University, Canberra, Australia.

Watson, D. 1989. The evolution of appropriate resource-management systems. Pages 54-69 in F. Berkes, editor. Common property resources: Ecology and community-based sustainable development. Belhaven Press, London, England.

Wright,A. 1985. Marine resource use in Papua New Guinea: can traditional concepts and contemporary development be integrated? Pages 53-77 in K. Ruddle, and R. E. Johannes, editors. The traditional knowledge and management of coastal systems in Asia and the Pacific. United Nations Educational, Scientific, and Cultural Organization, Jakarta Pusat, Indonesia.

Zanetell, B. A., and B. A. Knuth. 2004. Participation rhetoric or community-based management reality? Influences on willingness to participate in a Venezuelan freshwater fishery. World Development 32:793-807.

Zann, L. P. 1985. Traditional management and conservation of fisheries in Kiribati and Tuvalu atolls. Pages 53-77 in K. Ruddle, and R. E. Johannes, editors. The traditional knowledge and management of coastal systems in Asia and the Pacific. United Nations Environmental and Cultural Organization, Jakarta Pusat, Indonesia. 